латинском языке, или предоставляет заранее приготовленный перевод стихотворения с латинского на русский языки. Второй конкурсный день проводится конкурс иллюстраций, студенты выбирают любой латинский афоризм и представляют его в виде рисунка. На следующий день, студенты-члены научного кружка защищают свои проекты или выступают с докладами. Четвертый день посвящен «Интеллектуальной игре», где студенты соревнуются в знаниях по латинскому языку и мифологии. В пятницу, по традиции подводятся итоги внутривузовской олимпиады, задания выдаются студентам заранее и они выполняют ее дома. Завершающим днем является студенческая микроконференция, на которой, студенты представляют свои научно-исследовательские работы.

Таким образом, если преподаватель обладает глубокими научными знаниями по предмету, но не владеет методическим мастерством, он не сможет передать свои знания студентам. Преподаватель в высшей школе должен обладать определенными умениями: планировать работу со студентами, организовать свою деятельность на принципах коммуникативного общения. Чтобы увидеть своих студентов равноправными партнерами по общению, преподаватель должен быть хорошим собеседником, должен уметь общаться. Творческая деятельность преподавателей должна стать решающим фактором в формировании познавательного интереса к латинскому языку. Использование нетрадиционных методов на занятиях является важным стимулом мотивации учебнопознавательной деятельности студентов.

$$
* * *
$$

1. Гальскова Н.Д. Теория обучения иностранным языкам. Лингводидактика и методика / Н.Д. Гальскова, Н.И. Гез. - [5-е изд., стер.]. - М.: Издательский центр “Академия”, 2008. - 336 с.

2. Современные проблемы качественного образования в высшей школе: материалы межрегиональной межвузовской научно-практической конференции 1 февраля 2007, п/ред. Шеширов А.Л.идр. - 2007. 200c.

3. Хуторской А.В. Ключевые компетенции и образовательные стандарты // Интернет-журнал «Эйдос». 2002. — [Электронный ресурс]: Режим доступа: http://eidos.ru/journal/2002/0423.htm.

\title{
Баклушина И.В.
}

Деятельность куратора академической группы в ВУЗе

ФГБОУ ВО «Сибирский государственный индустриальный университет»

(Россия, Новокузнеик)

doi:10.18411/lj-07-2018-10

idsp: 000001:lj-07-2018-10

\section{Аннотация}

В статье приведена точка зрения на вопрос о необходимости работы куратора с академической группой и возможные пути повышения качества воспитательной и внеучебной работы. Также описаны некоторые формы и содержание работы куратора академической группы и возможное содержание дневника куратора.

Ключевые слова: куратор, воспитательная работа, внеучебная работа

Любое учебное заведение должно обеспечивать надлежащее качество образования, которое определено как сбалансированное соответствие всех аспектов высшего образования некоторым целям, потребностям, требованиям, нормам и стандартам [1]. В университете качество образования рассматривается в двух аспектах:

- качество результата образовательного процесса: соответствие уровня знаний обучающихся и выпускников требованиям государственного образовательного стандарта высшего профессионального образования;

- характеристики системы обеспечения этого качества: содержания образования, уровня подготовки абитуриентов, преподавательских кадров, 
информационно-методического обеспечения, материально-технического обеспечения качества подготовки, используемых образовательных технологий, научной деятельности.

Система менеджмента качества университета является совокупностью мероприятий, методов и средств, обеспечивающих реализацию качественного образовательного процесса на всех этапах от первоначального определения и до конечного удовлетворения требований и потребностей заинтересованных сторон. При этом наряду с другими аспектами на качество образовательной деятельности влияет учебно-воспитательная работа с обучающимися. Особенно важно ее влияние на начальном этапе обучения, а точнее, на младших курсах (первый и второй курсы).

Учебно-воспитательная (внеучебная) деятельность направлена на ориентацию обучающихся на самовоспитание, самореализацию своих лучших качеств и способностей. Основные цели и задачи воспитательной работы:

— формирование у обучающихся гражданской позиции, сохранение и развитие традиций университетского образования и воспитания;

- развитие творческих способностей обучающихся;

- направленная координация учебной и внеучебной деятельности преподавателей и студенческих общественных организаций.

Для достижения поставленных целей организацию внеучебной работы с обучающимися в Сибирском государственном индустриальном университете имеет три уровня иерархии:

- университетский уровень;

- факультетский уровень;

- кафедральный уровень.

На кафедральном уровне для организации внеучебной работы с академической группой на 1 и 2 курсах на основании распоряжения директора института по представлению заведующего кафедрой назначается куратор академической группы. Куратором назначается работник из числа профессорско-преподавательского состава выпускающей кафедры, имеющий стаж научно-педагогической деятельности, обладающий высокими морально-нравственными качествами и организаторскими способностями.

При этом необходимо отметить, что, как раз именно кафедральный уровень внеучебной работы с обучающимися имеет особое, крайне важное значение [1]. Кураторство - незаменимая и, при правильной организации, эффективная система взаимодействия преподавателей и обучающихся. Она позволяет решать многие задачи, в том числе оказывать обучающимся помощь в учёбе и в общественной жизни, передавать молодёжи жизненный опыт, знания, традиции, оказывать определённое воздействие на их мировоззрение и поведение.

На начальном этапе обучения студентов наиболее важна адаптация первокурсника в университете. Следует отметить, что обучающиеся первого курса весьма уязвимы с психологической точки зрения. В первые месяцы обучения в вузе обучающийся оказывается оторван от привычной школьной среды, знакомого коллектива одноклассников и учителей. Ему приходится заново доказывать свою успешность в конкурентной среде однокурсников, прилагая к этому значительные усилия. К тому же некоторая свобода и осознание своей «взрослости» и уменьшение контроля со стороны родителей (если обучающийся проживает в общежитии) могут повлиять на его усердие отрицательным образом. Такие условия могут способствовать ухудшению посещаемости занятий и отсутствию стимула к самостоятельной работе [2], что, в свою очередь, отрицательно влияет на успеваемость обучающегося и качество образовательной деятельности, так как помимо практической важности самостоятельная работа имеет большое воспитательное значение: она формирует самостоятельность не только как 
совокупность определенных умений и навыков, но и как черту характера, играющую существенную роль в структуре личности [3].

Куратор группы, это, по сути, практически единственный преподаватель в университете, к которому обучающийся может неформально обратиться со своими проблемами не только в учебе, но и в общении с преподавателями (не секрет, что между преподавателями и обучающимися нередко возникают конфликтные ситуации, результат которых сильно отражается на успеваемости обучающегося). Своевременное вмешательство куратора, а, при необходимости, заведующего профильной кафедрой при этом способно разрешить конфликт и, не редко, исправить ситуацию. Кроме того, даже при отсутствии каких либо проблемных ситуаций работа куратора способна улучшить качество внеучебной работы с обучающимися. Поэтому на этом этапе куратору необходимо:

- узнать о своих студентах как можно больше: сначала заочно, по карточке абитуриента, потом во время встреч и бесед (можно привлечь Студенческий совет факультета для анкетирования);

- создать в группе атмосферу доброжелательности, товарищества и взаимопомощи, выявить и подобрать актив группы (старосту, профорга);

- ознакомиться с условиями проживания студентов (особенно в общежитиях).

Исходя из обозначенных задач, содержание работы куратора группы может включать в себя:

- постоянное участие в жизни группы в течение учебного года: помощь в решении повседневных проблем, работа по созданию дружеской атмосферы в группе, интерес к личности каждого студента;

— контроль успеваемости обучающихся;

- знание бытовых и семейных условий и состояния здоровья обучающихся;

- помощь в вопросах, связанных с учебным расписанием, занятиями, сессией;

- привлечение обучающихся к исследовательской работе, изучение их научных интересов;

- приобщение обучающихся к студенческой жизни, предоставление возможности для самореализации;

- индивидуальная работа с обучающимися: как с теми, у которых возникают проблемы с адаптацией в университете, так и с теми, кто стремится к более глубокому изучению учебных дисциплин. Взаимоотношения с сокурсниками, преподавателями, личные проблемы также должны находиться в поле зрения куратора;

- доведение до сведения института и родителей необходимой информации об успеваемости, посещении занятий и поведении в университете;

- этическое и эстетическое воспитание обучающихся: беседы о поведении, этикете, привитие интереса к культуре, искусству. Контроль соблюдения ими правил внутреннего распорядка в университете.

Составление специального дневника куратора облегчает и упрощает обратную связь с обучающимися. Для этого необходимо вносить в дневник куратора некоторые сведения об обучающихся и их родителях. Опыт работы кураторов на кафедре теплогазоводоснабжения, водоотведения и вентиляции Сибирского государственного индустриального университета показал, что это должны быть следующие сведения:

— расписание занятий академической группы;

- список группы;

- личные сведения об обучающихся (даты рождения; средний балл аттестата о предыдущем образовании; адреса проживания и контактные телефоны как самих обучающихся, так и их родителей) 
— ведомости аттестаций по семестрам;

- план работы куратора на текущий семестр (в конце семестра заведующий кафедрой делает соответствующие отметки о выполнении плана по пунктам);

- список проведенных мероприятий (данный раздел удобно вести в виде таблицы, включающей следующие колонки: дата мероприятия, описание мероприятия).

Работу куратора целесообразно организовывать в несколько этапов:

1. Заочное знакомство с группой. Наиболее целесообразно начинать за несколько дней до начала учебного года. Работа куратора в этот период заключается в подготовке списка группы (занесения его в журнал куратора), ознакомление с информацией карточки абитуриента: выявление потенциальных лидеров, заведомо слабых по успеваемости обучающихся (согласно школьным оценкам). При этом в первый учебный день куратор:

- присутствует вместе с обучающимися группы на торжественных мероприятиях;

— помогает разобраться с учебным расписанием;

— организует первое знакомство с группой;

- проводит знакомство с учебным корпусом, чтобы помочь обучающимся освоиться в стенах университета;

- настраивает обучающихся на серьёзное и ответственное отношение к учёбе, к жизни в университете, на бережное отношение к материальным ценностям, предоставленным в их пользование (аудитории, парты, оргтехника и т.п.)

2. Знакомство в группе. Хорошо подготовленное и проведённое знакомство группы позволяет, во-первых, обучающимся лучше узнать своих однокурсников, вовторых, получить максимальную информацию об обучающихся. Для того, чтобы быстрее и успешнее познакомить обучающихся друг с другом существует множество методик, но самым эффективным методом может оказаться проведение вечера знакомств, что предполагает специально организованное общение группы во внеучебное время в неформальной обстановке.

3. Выбор актива группы. Актив группы выбирается в сентябре. Актив группы состоит из старосты и, при необходимости, профорга, которые избираются на общем собрании группы. Куратор должен организовать проведение выборов актива. До того как проводить выборы, необходимо ознакомить обучающихся с правами и полномочиями представителей актива. Нельзя допускать, чтобы кандидатуру выбирали против его желания, а также, чтобы обучающиеся равнодушно относились к выбору актива группы. Задача куратора во время выборов актива группы состоит в том, чтобы настроить обучающихся на серьёзное отношение к происходящему и не влиять на принятие решений (даже если будет казаться, что выбор сделан неверным).

4. Знакомство с институтом, университетом (историей, традициями, требованиями к обучающимися) необходимо начать с 1 сентября и продолжать в течение двух-трёх месяцев. Это возможно выполнять одним или комбинацией нескольких приемов:

- заочное знакомство: беседы с группой, лекции или просмотр фильмов об истории факультета (если есть), университета;

- экскурсия по институту, по наиболее интересным и необходимым местам в университете (библиотека, столовая, здравпункт, профком, музей, шахматный клуб и т.п.);

- знакомство со студенческой жизнью в университете: с системой студенческого самоуправления, художественной самодеятельностью, спортом; 
- с подразделениями ректората: учебно-методическим управлением, студенческим отделом кадров;

- ознакомление с Уставом университета, разъяснение основных правил, прав и обязанностей студентов;

- участие в занятиях, где происходит знакомство с библиотекой университета, так как многие студенты не сразу усваивают правила пользования библиотекой.

5. Час куратора. В это время первокурсники получают возможность правильно сориентироваться в новой для них обстановке и, самое главное, в этот момент закладывается основа патриотизма к своему университету [3].

Рекомендуется проводить регулярно, желательно не реже одного раза в месяц, а в первые месяцы обучения обучающихся на первом курсе раз в неделю. Примерная тематика часа куратора:

- решение повседневных проблем и вопросов, появившихся у группы;

- обсуждение актуальных вопросов современной жизни (знание и защита собственных прав, ценность семьи для современной молодёжи, городской и сельский образ жизни и т.д.);

- встречи с директором института, знаменитыми выпускниками факультета, специалистами, представителями общественных организаций и др.;

- проведение деловых игр на коллективное взаимодействие, на сплочение и развитие доверия обучающихся друг к другу;

- беседы с отдельными обучающимися об их успеваемости, посещаемости, участии в делах группы, института, университета.

6. Помощь обучающимся в учёбе и профессиональном росте. Куратор академической группы обязан анализировать итоги экзаменационных сессий, после чего необходимо проводить собрания группы и беседы с отстающими обучающимися. Положительный эффект приносит практика оповещения родителей об успеваемости обучающихся: отстающие прилагают больше усилий по сдаче сессии, а выражение благодарности за учёбу обучающегося мотивирует последнего на поддержание успеваемости или её повышение. На заседаниях выпускающих кафедр кураторы отчитываются за свою работу, на них же могут быть приглашены и преподаватели общих кафедр. Таким образом, достигается координация усилий кураторов и преподавателей.

По окончании каждого учебного семестра необходимо составить письменный отчёт и сдать его заместителю директора института. В отчете необходимо отразить наиболее важные этапы и результаты работы куратора:

- общие сведения о группе; успеваемость в группе, динамика успеваемости за год; достижения в спорте, культуре, общественной деятельности, данные об активистах, интересах),

— проведённая куратором работа (периодичность работы с группой; план работы: мероприятия и дела, индивидуальная работа с обучающимися (если проводилась); анализ проведённой работы: какой эффект дали проведённые мероприятия, беседы, часы куратора, индивидуальная работа; работа с родителями (если проводилась, был ли эффект); выводы о проделанной работе, пожелания).

Таким образом, работа всего коллектива университета должна быть направлена на формирование этого мировоззрения, и здесь очень важна координация деятельности всех сотрудников и служб (посещение культурных мест города, области: музеев, выставок, театров; проведение юбилеев, тематических вечеров, встреч с выдающимися учёными, поездки по родному краю, конкурсы рефератов и т.п.). Немаловажно воспитание у обучающихся уважения и доброжелательности к людям других взглядов, 
национальностей, вероисповеданий. Все это позволит повысить качество образовательной деятельности и, как следствие, рейтинг и конкурентоспособность университета.

$$
* * *
$$

1. Баклушина И.В. Работа куратора академической группы в вузе / Современные вопросы теории и практики обучения в вузе: сборник научных трудов. Вып. 11 / Редкол.: А.В. Феоктистов (главн. ред.) и др. / Сиб. гос. индустр. ун-т. - Новокузнецк: СибГИУ, 2010. - 235 с., ил. - С. 54-59.

2. Баклушина И.В., Башкова М.Н. Организация и контроль самостоятельной работы студентов // Вестник СибГИУ. - 2014. - № 4. - С.62-65.

3. Баклушина И.В., Смирнова Е.В., Шамариков А.А. Влияние работы куратора на качество образовательной деятельности //Вестник горно-металлургической секции Российской академии естественных наук. Отделение металлургии. - 2015. - № 34. - С.165-168.

\section{Вилкова А.В. \\ Определение девиантного поведения}

Научно-исследовательский институт ФСИН России

(Россия, Москва)

doi:10.18411/lj-07-2018-11

idsp: 000001:lj-07-2018-11

\section{Аннотация}

В статье рассматривается вопрос определения девиантного поведения, дана его характеристика и определена норма поведения, которая базируется на трех составляющих индивидуальности, аномалии и девиации

Ключевые слова: девиантное поведение, адаптивность, норма

Широкая область научного знания охватывает аномальное, девиантное поведение человека. Существенный параметр такого поведения - отклонение в ту или иную сторону с различной интенсивностью и в силу разнообразных причин от поведения, которое признается нормальным и неотклоняющимся.

Характеристиками нормального и гармоничного поведения считаются:

- сбалансированность психических процессов (на уровне свойств темперамента);

- адаптивность и самоактуализация (на уровне характерологических особенностей) и духовность;

- ответственность и совестливость (на личностном уровне).

Также как норма поведения базируется на этих трех составляющих индивидуальности, и аномалии и девиации основываются на их изменениях, отклонениях и нарушениях. Таким образом, девиантное поведение человека - это система поступков или отдельные поступки, противоречащие принятым в обществе нормам и проявляющиеся в виде несбалансированности психических процессов, неадаптивности, нарушения процесса самоактуализации или уклонений от нравственного и эстетического контроля за собственным поведением.

Считается, что взрослый индивид изначально обладает стремлением к «внутренней цели», в соответствии с которой осуществляются все без исключения проявления его активности («постулат сообразности», по В.А. Петровскому). Речь идет об изначальной адаптивной направленности любых психических процессов и поведенческих актов. Выделяют различные варианты «постулата сообразности»: гомеостатичсский, гедонический, прагматический. При гомеостатическом варианте «постулат сообразности» выступает в форме требования к устранению конфликтности во взаимоотношениях со средой, установлению «равновесия». При гедоническом варианте действия человека детерминированы двумя первичными аффектами: удовольствием и страданием - и все поведение интерпретируется как максимализация удовольствия и 